\title{
Inovasi Produk terhadap Keputusan Pembelian dan Dampaknya terhadap Loyalitas Pelanggan : Studi Pengguna Mobil Toyota Calya di Kota Bogor dan Bekasi
}

\author{
Anugerah Dachi ${ }^{*}$ \\ STIE Manajemen Bisnis Indonesia, Depok, Indonesia \\ anugerahdachi122@gmail.com
}

\begin{abstract}
The formulation of the research problemis whether product innovation effects purchase decisions, whether product innovation and purchase decisions affect customer loyalty. This study aims to examine the effect of product innovation on the purchase decision of Toyota Calya, and examines the effect of product innovation and purchasing decisions on customer loyalty. The population is the Toyota Calya's customers in Bogor and Bekasi. The population is not known with certainty, therefore the sampling technique is done by accidental sampling technique in determining the number of samples. A total of 203 questionnaires were collected. Therefore, the sample in this study was 203 respondents. The data analysis method is Structural Equation Modeling. The results showed a significant influence onproduct innovation on purchasing decisions. Product innovation and purchasing decision also significantly influence customer loyalty. Purchasing decisions significantly mediate the effect of product innovation on customer loyalty. Innovations must still be made in order to maintain the loyalty of Toyota Calya car users in Bogor and Bekasi.
\end{abstract}

Keywords: Product innovation, purchasing decisions, and loyalty

\begin{abstract}
Abstrak
Rumusan masalah penelitian ini adalah apakah inovasi produk mempengaruhi keputusan pembelian, dan apakah inovasi produk dan keputusan pembelian mempengaruhi loyalitas pelanggan. Penelitian ini bertujuan untuk menguji dan mengetahui pengaruh inovasi produk terhadap keputusan pembelian toyota Calya, dan menguji pengaruh inovasi produkdan keputusan pembelian terhadap loyalitas pelanggan. Populasi penelitian adalah pengguna mobil merek Toyota Calya di Kota Bogor dan Bekasi. Populasi tidak diketahui secara pasti,oleh karena itu teknik pengambilan sampel dilakukan dengan teknik accidental sampling dalam menentukan jumlah sampel. Kuisioner yang berhasil dikumpulkan sebanyak 203 kuisioner. Metode analisis data yang dipergunakan adalah Structural Equation Modeling. Hasil penelitian menunjukkan adanya pengaruh secara signfikan inovasi produk dengan keputusan pembelian. Variabel Inovasi produk dan keputusan pembelian jugasecara signifikanmempengaruhi loyalitas pelanggan. Keputusan pembelian secara signifikan memediasi pengaruh inovasi produk terhadap loyalitas pelanggan.Inovasi harus tetap dilakukan untuk mempertahankan loyalitas pengguna mobil Toyota Calya di Kota Bogor dan Bekasi.
\end{abstract}

Kata kunci :Inovasi produk, keputusan pembelian,dan loyalitas

\section{Pendahuluan}

Persaingan yang semakin ketat dalam dunia bisnis menuntut setiap perusahaan untuk merancang dan menerapkan berbagai macam strategi yang tepat (Istiyanto, Hendratmoko, \& Mutmainah, 2015). Situasi lingkungan yang dinamis dan terus berkembang,maka perusahaan tidak cukup mempertahankan sikap menarik pelanggan atau memperluas usaha baru. Tantangan yang dihadapi adalah mempertahankan loyalitas pelanggan (Syafrizal, Makmur, \& Seprini, 2017). 
Berdasarkan data yang berhasil dikumpulkan menunjukkan bahwa penjualan mobil Toyota Calya masih kalah bersaing dengan produk lainnya. Pada Tabel 1 penulis menampilkan perbandingan penjualan mobil Calya, Avanza, dan Daihatsu Sigra dari Mei 2019 sampai dengan April 2020.

Tabel 1Perbandingan Penjualan Calya, Avanza, Daihatsu Sigra

Mei 2019 - April 2020

\begin{tabular}{llccc}
\hline No & Bulan & Calya & Avanza & Daihatsu Sigra \\
\hline 1 & Mei & 3.877 & 7.362 & 4.957 \\
2 & Juni & 3.963 & 3.543 & 1.186 \\
3 & Juli & 5.167 & 7.848 & 3.757 \\
4 & Agustus & 3.436 & 8.017 & 4.371 \\
5 & September & 6.111 & 9.476 & 3.932 \\
6 & Oktober & 6.034 & 8.816 & 5.191 \\
7 & November & 5.119 & 6.764 & 4.429 \\
8 & Desember & 4.726 & 6.674 & 4.705 \\
9 & Januari & 4.579 & 7.080 & 3.705 \\
10 & Februari & 3.645 & 7.080 & 4.363 \\
11 & Maret & 3.806 & 7.085 & 5.399 \\
12 & April & 62 & 277 & 479 \\
\hline & Rata-rata penjualan & 4.210 & 5.488 & 3.872 \\
\hline
\end{tabular}

Sumber :www.otosia.com, www.otomotif.tempo.co, www.oto.detik.com, www.gridoto.com

Tabel 1 juga menunjukkan bahwa penjulaan mobil Toyota Calya sempat mengalami kenaikan pada bulan Agustus dan September 2019, namun mulai dari November 2019 sampai dengan April 2020 terus mengalami penurunan. Secara rata-rata, jika dibandingkan dengan merek lain, penjualan Toyota Calya lebih rendah dari penjualan mobil Avanza. Rata-rata penjualan Toyota Calya sedikit diatas penjualan Daihatsu Sigra, namun jika dilihat data tiga bulan terakhir, penjualan Daihatsu Sigra terus mengalami peningkatan dan jumlah penjualan setiap bulannya jauh di atas penjualan Toyota Cayla. Pada April 2020 penjualan mobil secara umum turun drastis, hal ini disebabkan karena adanya Covid 19 yang telah menurunkan daya beli masyarakat. Namun ditengah pandemi Covid 19, penjualan Daihatsu Sigra jauh lebih tinggi dibandingkan dengan Toyota Calya yang hanya mampu menjual sebanyak 62 unit, Daihatsu Sigra sebanya 479 unit.

Pengembangan produk melalui inovasi yang dilakukan oleh perusahaan dapat menciptakan keunggulan kompetitif selain itu akan menarik pelanggan baru, sementara pelanggan yang sudah ada akan tetap bertahan (Sumarsih, 2019). Keputusan pembelian adalah tindakan konsumen dalam usaha memenuhi keinginan dan kebutuhan yang merupakan proses penentuan sikap atau pembelian terhadap barang dan jasa untuk memahami perilaku konsumen dalam pembelian membutuhkan proses, dikarenakan setiap saat mengalami perubahan (Kadir, Syarifuddin, Rahman, \& Andini, 2018). Dalam persaingan global, perusahaan otomotif harus terus berinovasi karena teknologi yang cepat berkembang selain itu agar dapat terus bersaing dengan kompetitor dan untuk memenuhi kebutuhan dan selera konsumen(Tandia \& Iriani, 2018). Inovasi merupakan sesuatu yang mutlak untuk mencapai keunggulan berkelanjutan(Siregar, Suryana, Ahman, \& Senen, 2019). Setiap perusahaan berkepentingan terhadap kinerja terbaik yang mampu dihasilkan oleh rangkaian sistem yang berlaku dalam organisasi tersebut (Syamsuri \& Siregar, 2018; Siregar \& Lubis, 2017). Banyak produk yang memiliki kesamaan bentuk, kegunaan dan fitur-fitur lain membuat konsumen kesulitan untuk membedakan produk-produk tersebut. Inovasi produk terus 
dilakukan oleh produsen mobil untuk menarik perhatian konsumen dan tentu saja agar konsumen bersedia membeli produk yang dihasilkannya (Tumembouw, Mandey, \& Loindong, 2019).

Berdasarkan uraian sebelumnya, maka pertanyaaan penelitian dalam penelitian ini adalah :

1. Apakah inovasi produk berpengaruh positif dan signifikan terhadap keputusan pembelian?

2. Apakah inovasi produk berpengaruh positif dan signifikan terhadap loyalitas?

3. Apakah keputusan pembelian berpengaruh positif dan signifikan terhadap loyalitas?

4. Apakah keputusan pembelianmemediasi pengaruh inovasi produk terhadap loyalitas pelanggan?

\section{Loyalitas Pelanggan}

Secara harfiah loyal dapat bermakna setia, sedangkan loyalitas dapat diartikan sebagai suatu kesetiaan. Loyalitas pelanggan adalah komitmen pelanggan terhadap suatu merek, toko atau pemasok, berdasarkan sikap yang sangat positif dan tercermin dalam pembelian ulang yang konsisten (Bulan, 2016). Loyalitas pelanggan memiliki peran penting dalam sebuah perusahaan, mempertahankan mereka berarti meningkatkan kinerja dan mempertahankan kelangsungan hidup perusahaan. Hal ini merupakan salah satu alasan perusahaan untuk mempertahankan pelanggan mereka (Saputri, 2019).

Konsep perilaku loyal, penekanannya adalah perilaku pembelian ulang atas produk yang penah dibeli oleh pelanggan (Junaedi, 2015). Untuk menjaga kelangsungan bisnis, loyalitas pelanggan sangat penting bagi perusahaan. Pelanggan yang setia atau loyal merupakan pelanggan yang sangat puas dengan pilihan produk dan pelayanan tertentu dari perusahaan, sehingga mempunyai antusiasme untuk mengatakan hal-hal yang positif tentang produk tersebut dan pelayanan yang mereka terima kepada orang lain (Tugiso, Haryono, \& Minarsih, 2016).

\section{Keputusan Pembelian}

Pembelian dapat diartikan sebagai tindakan untuk mendapatkan barang dan jasa melalui pertukaran, yang dimaksudkan untuk digunakan sendiri maupun untuk dijual kembali (Khairiyah \& Yunita, 2018). Konsumen yang ingin melakukan pembelian akan melewati suatu proses yang dinamakan keputusan pembelian sebelum memutuskan membeli sebuahproduk (Tandia \& Iriani, 2018). Menurut Kotler dan Armstrong (dalam Tandia \& Iriani, 2018) keputusan pembelian memiliki arti membeli merek yang paling disukai, tetapi dua faktor bisa berada antara niat melakukan pembelian dan melakukan keputusan pembelian. Proses pengambilan keputusan pembelian itu sendiri dapat melalui tahapanseperti tahapan mengenali kebutuhan, pencarian informasi, evaluasi, alternatif, keputusan membeli, dan perilaku konsumen pasca pembelian, namun tidak selalu semua tahap tesebut dilalui atau dilaksankan oleh konsumen secara keseluruhan (Setiadi 2013 dalam Kadir et al., 2018).

\section{Inovasi Produk}

Inovasi produk adalah setiap barang atau produk yang telah dikembangkan atau dimodifikasi yang dianggap yang baru (Tandia \& Iriani, 2018). Inovasi produk berkaitan dengan salah satu pengembangan suatu produk atau sebuah hal baru yang ditemukan, hal ini dilakukan supaya konsumen tidak bosan dengan produk lama yang dihasilkan (Aryoni, Eildine, \& Muniroh, 2019). Inovasi yang dilakukan atas produk oleh perusahaan dianggap dapat menghilangkan perasaan jenuh atau kebosanan konsumen atas pilihan produk oleh konsumen yang cenderung kurangnyakeberagaman sertatidak mempunyai keunikan (Al rasyid \& Tri Indah, 2015). Dengan inovasi yang dilakukan industri atau perusahaan, akan memberikan nilai tambah terhadap produk yang dimiliki sehingga harapan konsumen akan terpenuhi. Salah satu manfaat dari inovasi bertujuan mempercantik produk sehingga lebih menarik bagi para konsumen (Sumarsih, 2019). 


\section{Pengembangan Hipotesis}

\section{Inovasi Produkdan Keputusan Pembelian}

Soleha \& S, (2019) melakukan sebuah penelitian tentang inovasi produk keputusan pembelian mobil Honda Mobilio. Temuan penelitian mereka menemukan ada pengaruh yang positif dan signifikan antara inovasi produk terhadap keputusan pembelian. Hal ini menunjukkan bahwa dengan adanya inovasi produk maka akan menjadi pertimbangan dalam memutuskan untuk membeli. Diperkuat juga dengan hasil temuan penelitian yang dilakukan oleh (Abdjul, Soegoto, \& Soepeno, 2018) menunjukkan bahwa inovasi produk berpengaruh positif dan signifikan terhadap keputusan pembelian. Untuk meningkatkan keputusan dan kesetiaan pelanggan maka inovasi produk harus tetap dilakukan secara berkelanjutan.

\section{Inovasi Produk dan Loyalitas}

Inovasi produk berpengaruh terhadap loyalitas pelanggan. Artinya dengan adanya inovasi produk akan membuat pelanggan untuk terus bertahan menggunakan produk tersebut. Penelitian sebelumnya telah membuktikan bahwa ada pengaruh antara inovasi produk terhadap loyalitas. Syafrizal, Makmur, \& Seprini (2017) dalam penelitiannya menyimpulkan bahwa loyalitas pelanggan dipengaruhi oleh inovasi produk. Temuan penelitian yang sama juga ditemukan oleh Aryoni dkk (2019) dalam penelitiannya menemukan bahwa ada pengaruh antara inovasi produk terhadap loyalitas konsumen.

\section{Keputusan Pembelian dan Loyalitas}

Seorang pelanggan yang telah melakukan pembelian akan membentuk perilaku loyal ataupun tidak loyal. Hal ini tergantung bagaimana persepsi pelanggan terhadap produk yang telah dibeli. Jika pelanggan merasa positif atas produk yang dibeli, pelanggan akan loyal. Sementara jika pelanggan mengalami persepsi yang negatif atas produk yang dibeli, pelanggan akan tidak loyal dan beralih ke produk lain. Penelitian berkaitan dengan hubungan keputusan pembelian terhadap loyalitas pernah dilakukan oleh Hendriko, (2018) menemukan bahwa keputusan pembelian mempengaruhi loyalitas pelanggan. Penelitian yang dilakukan oleh (Rejeki, H, \& Yulianto, 2015) juga menemukan bahwa ada keputusan memiliki pengaruh terhadap loyalitas pelanggan.Kerangka konseptual penelitian dapat digambarkan sebagai berikut.

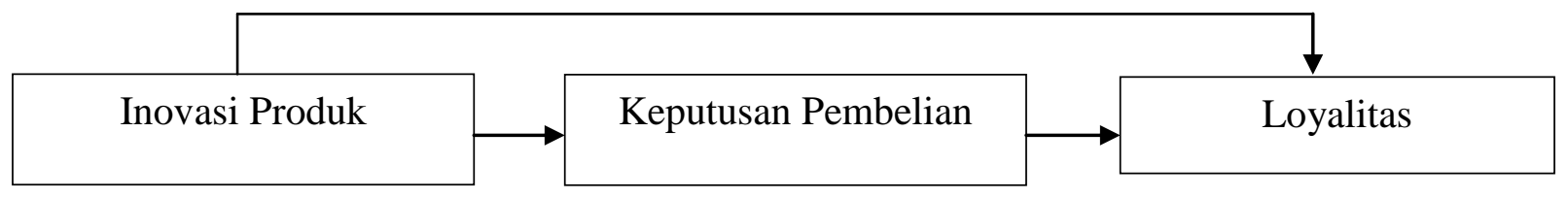

Gambar 1. Kerangka Konseptual Penelitian

\section{Metode Penelitian}

Pendekatan penelitian ini adalah pendekatan penelitian kuantitatif. Populasi dalam penelitian ini adalah pengguna mobil merek Toyota Calyadi Kota Bogor dan Bekasi. Teknik pengambilan sampel dengan teknik accidental samplingyang berarti pengambilan sampel dilakukan kepada pengguna mobil Calya yang kebetulan bertemu dengan peneliti. Kuisioner berhasil dikumpul sebanyak 203 kuisioner.Oleh karena itu, sampel dalam penelitian ini adalah sebanyak 203 orang. Penggunaan sampel sebanyak 203 responden sudah memenuhi syarat dalam menganalisis data denganStructural Equation Modelingyang merekomendasikan sampel di atas 200 responden (Hair dkk, 2017). Analisis data dilakukan dengan Structural Equation Modeling. Dalam 
penelitian terdapat tiga variabel penelitian, yaitu inovasi produk, keputusan pembelian dan loyalitas pelanggan. Pengukuran masing-masing variabel dapat dilihat pada Tabel 2.

Tabel 2. Pengkuran Variabel Penelitian

\begin{tabular}{|c|c|}
\hline Variabel & Indikator/Item pernyataan \\
\hline \multirow{5}{*}{$\begin{array}{l}\text { Inovasi Produk } \\
\text { (Ekasari \& Roza, 2017), } \\
\text { (Al rasyid \& Tri Indah, } \\
\text { 2015) }\end{array}$} & Jenis produk Toyota Calyaberagam \\
\hline & Peningkatan kualitas produk selalu dilakukan \\
\hline & Desain produk selalu ditingkatkan \\
\hline & Ketersediaan suku cadang \\
\hline & Kinerja mesin sangat bagus \\
\hline \multirow{5}{*}{$\begin{array}{l}\text { Keputusan Pembelian } \\
\text { (Al rasyid \& Tri Indah, } \\
\text { 2015) }\end{array}$} & Saya menggunakan produk Toyota Calya untuk memenuhi kebutuhan mobilitas \\
\hline & Saya mencari informasi tentang Toyota Calya sebelum melakukan pembelian \\
\hline & Saya melakukan evaluasi merek lain sebelum memutuskan untuk membeli \\
\hline & Saya yakin dengan keputusan saya untuk membeli produk Toyota Calya \\
\hline & Saya merasa puas setelah melakukan pembelian produk Toyota Calya \\
\hline \multirow{6}{*}{$\begin{array}{l}\text { Loyalitas Pelanggan } \\
\text { (Bobâlcă, Gătej(Bradu), \& } \\
\text { Ciobanu, 2012) }\end{array}$} & Untuk transportasi, saya lebih menyukai produk Toyota Calya daripada produk lain \\
\hline & Saya merasa sangat senang menggunakan produk ini \\
\hline & Saya membeli produk ini karena saya sangat menyukainya \\
\hline & Saya akan terus membeli produk Toyota Calyauntuk kedepannya. \\
\hline & Saya merekomendasikan produk Toyota Calya kepada orang lain \\
\hline & $\begin{array}{l}\text { Saya menyampaikan hal yang positif tentang produk Toyota Calya kepad } \\
\text { lain }\end{array}$ \\
\hline
\end{tabular}

\section{Temuan Penelitian}

\subsection{Uji Normalitas}

Salah satu persyaratan yang dipenuhi dalam metode analisis data menggunakan Structural Equation Modeling adalah data harus berdistribusi secara normal. Menurut Schumacker \& Lomax, (2010) merekomendasikan nilai cr $< \pm 2.58$ dan Nilai skewness dan kurtosis dari semua indikator berada dibawah $<2.58$ (Schumacker \& Lomax, 2010).

Tabel 3. Uji Normalitas

\begin{tabular}{lrrrr}
\hline Variable & skew & c.r. & kurtosis & c.r. \\
\hline Loy6 &,- 319 & $-1,855$ &,- 295 &,- 857 \\
Loy5 &,- 378 & $-2,199$ &,- 173 &,- 502 \\
Loy4 &,- 220 & $-1,278$ &,- 266 &,- 772 \\
Loy3 &, 128 &, 742 &,- 229 &,- 667 \\
Loy2 &, 038 &, 220 &,- 245 &,- 714 \\
Loy1 &, 009 &, 054 &,- 293 &,- 853 \\
Kep1 &, 008 &, 046 &,- 223 &,- 647 \\
Kep2 &,- 052 &,- 301 &,- 267 &,- 776 \\
Kep3 &, 079 &, 459 &,- 384 & $-1,117$ \\
Kep4 &,- 202 & $-1,177$ &,- 040 &,- 116 \\
Kep5 &,- 049 &,- 282 &,- 538 & $-1,564$ \\
Ino5 &,- 048 &,- 282 &,- 267 &,- 777 \\
Ino4 &,- 061 &,- 356 &,- 369 & $-1,073$ \\
Ino3 &,- 044 &,- 258 &,- 378 & $-1,098$ \\
Ino2 &, 159 &, 926 &,- 611 & $-1,777$ \\
Ino1 &,- 001 &,- 004 &,- 411 & $-1,197$ \\
\hline Multivariate & & & 6,070 & 1,802 \\
\hline Sumber : Hasil olah data, 2020 & & &
\end{tabular}

Sumber : Hasil olah data, 2020 
Tabel 3 menunjukkan bahwa nilai nilai cr memiliki nilai $< \pm 2.58$ dan nilai skewness and kurtosis dari semua indikator berada dibawah $<2.58$. Hal ini menunjukkan bahwa data dalam penelitian ini berdistribusi normal. Dengan demikian dapat dilanjutkan untuk tahapan selanjutnya.

\subsection{Model Pengukuran}

Untuk mengetahui apakah indikator yang digunakan untuk mengukur setiap variabel penelitian maka dilakukan model pengukuran menggunakan Confirmatory Factor Analysis (CFA). Nilai faktor loading yang disyaratkan adalah lebih besar 0.50, nilai CR (Composite Reliablity) direkomendasikan $\geq 0.70$ dan AVE (Average Variance Extracted) $\geq 0,50$ (Hair et al, 2017. Tabel 4 menunjukkan bahwa semua indikator memiliki loading factor $>0.50$, nilai $\mathrm{CR}$ $>0,70$, nila AVE $>0.50$. Dengan demikian, indikator yang digunakan dalam penelitian ini valid dan reliabel.

Tabel 4. Model Pengukuran

\begin{tabular}{|c|c|c|c|c|c|}
\hline Variabel & Indikator & $\begin{array}{c}\text { Factor } \\
\text { Loading }\end{array}$ & $\mathbf{C R}$ & AVE & Keterangan \\
\hline \multirow{5}{*}{$\begin{array}{l}\text { Inovasi } \\
\text { Produk }\end{array}$} & Jenis produk Toyota Beragam & 0,673 & \multirow{5}{*}{0.847} & \multirow{5}{*}{0.525} & \multirow{5}{*}{$\begin{array}{l}\text { Valid dan } \\
\text { Reliabel }\end{array}$} \\
\hline & $\begin{array}{l}\text { Peningkatan kualitas produk selalu } \\
\text { dilakukan }\end{array}$ & 0,721 & & & \\
\hline & Desain produk selalu ditingkatkan & 0,74 & & & \\
\hline & Ketersediaan suku cadang & 0,725 & & & \\
\hline & Kinerja mesin sangat bagus & 0,761 & & & \\
\hline \multirow{5}{*}{$\begin{array}{l}\text { Keputusan } \\
\text { Pembelian }\end{array}$} & $\begin{array}{l}\text { Menggunakan Toyota Calya untuk } \\
\text { memenuhi kebutuhan mobilitas }\end{array}$ & 0,676 & \multirow{5}{*}{0,835} & \multirow{5}{*}{0,503} & \multirow{5}{*}{$\begin{array}{l}\text { Valid dan } \\
\text { Reliabel }\end{array}$} \\
\hline & $\begin{array}{l}\text { Saya mencari informasi tentang produk } \\
\text { Toyota Calya sebelum melakukan } \\
\text { pembelian }\end{array}$ & 0,746 & & & \\
\hline & $\begin{array}{l}\text { Saya melakukan evaluasi merek lain } \\
\text { sebelum memutuskan untuk membeli }\end{array}$ & 0,733 & & & \\
\hline & $\begin{array}{l}\text { Saya yakin dengan keputusan saya untuk } \\
\text { membeli produk Toyota Calya }\end{array}$ & 0,665 & & & \\
\hline & $\begin{array}{l}\text { Saya merasa puas setelah melakukan } \\
\text { pembelian produk Toyota Calya }\end{array}$ & 0,724 & & & \\
\hline \multirow{6}{*}{ Loyalitas } & $\begin{array}{l}\text { Untuk alat transportasi, saya lebih } \\
\text { menyukai produk Toyota Calya daripada } \\
\text { produk lain }\end{array}$ & 0,743 & \multirow{6}{*}{0,879} & \multirow{6}{*}{0,547} & \multirow{6}{*}{$\begin{array}{l}\text { Valid dan } \\
\text { Reliabel }\end{array}$} \\
\hline & $\begin{array}{l}\text { Saya merasa sangat senang menggunakan } \\
\text { produk Toyota Calya }\end{array}$ & 0,737 & & & \\
\hline & $\begin{array}{l}\text { Saya membeliki produk ini karena saya } \\
\text { sangat menyukainya }\end{array}$ & 0,711 & & & \\
\hline & $\begin{array}{l}\text { Saya akan terus membeli produk Toyota } \\
\text { untuk kedepannya. }\end{array}$ & 0,713 & & & \\
\hline & $\begin{array}{l}\text { Saya merekomendasikan produk Toyota } \\
\text { kepada orang lain }\end{array}$ & 0,749 & & & \\
\hline & $\begin{array}{l}\text { Saya menyampaikan hal-hal yang positif } \\
\text { tentang produk Toyota Calya kepada orang } \\
\text { lain }\end{array}$ & 0,786 & & & \\
\hline
\end{tabular}

Sumber : Hasil olah data, 2020 


\subsection{Uji Kesesuain Model}

Hasil uji kesusuaian model dapat dilihat pada Tabel 5 dibawah ini.

Tabel 5. Uji Kesesuaian Model

\begin{tabular}{|c|c|c|}
\hline Kriteria & Hasil & Keputusan \\
\hline P-Value & 0.053 & Good Fit \\
\hline $\mathrm{Cmin} / \mathrm{DF}$ & 1.237 & Good Fit \\
\hline Adjusted Goodness of Fit (AGFI) & 0.902 & Good Fit \\
\hline The goodness of Fit Index (GFI) & 0.927 & Good Fit \\
\hline Comparative Fit Index (CFI) & 0.984 & Good Fit \\
\hline Tucker Lewis Index (TLI) & 0.981 & Good Fit \\
\hline Root Mean Square Error of & 0.034 & Good Fit \\
\hline
\end{tabular}

Sumber : Hasil olah data, 2020

Menurut Hair et al, (2017) beberapa kriteria uji kesesuaian model adalah Adjusted GFI $($ AGFI) > 0.90, Goodness_of Fit Index (GFI) > 0.90, CFI > 0.90, TLI > 0.90, RMSEA < 0.08, and RMR < 0.05 (Hair et al, 2017). Berdasarkan data yang disajikan pada tabel 5 menunjukkan bahwa model dalam penelitian ini fit.

\subsection{Uji Hipotesis}

Untuk pengujian hipotesis dalam penelitian ini dapat dilihat dari nilai critical ratio yang direkomendasikan yaitu lebih besar dari 1.96 dan nilai sig. probability lebih kecil dari 0.05 (Byrne, 2010). Hasil uji hipotesis dalam penelitian ini dapat dilihat pada Tabel 6 berikut ini :

Tabel 6.Hasil Uji Hipotesis

\begin{tabular}{lclccc}
\hline & \multicolumn{2}{c}{ Bentuk Hubungan } & $\begin{array}{c}\text { Standardized } \\
\text { Regresion Weigh }\end{array}$ & C.R. & P \\
\hline Inovasi Produk & $\rightarrow$ & Keputusan Pembelian &, 617 & 6,417 & .000 \\
\hline Inovasi produk & $\rightarrow$ & Loyalitas &, 282 & 3,368 & .002 \\
\hline Keputusan Pembelian & $\rightarrow$ & Loyalitas &, 619 & 6,326 & .000 \\
\hline Sumber: Data diolah, 2020 & & & & &
\end{tabular}

Sumber : Data diolah, 2020

Hasil pengujian hipotesis dapat dijelaskan sebagai berikut.

\section{Pengaruh Inovasi Produk terhadap Keputusan Pembelian}

Hipotesis pertama yang dikembangkan dalam penelitian ini adalah bahwa terdapat pengaruh yang positif dan signifikan antara inovasi produk terhadap keputusan pembelian. Hasil uji hipotesis terbukti bahwa ada pengaruh yang positif dan signifikan antara inovasi produk terhadap keputusan pembelian. Hal ini dapat dilihat dari perolehan nilai koefisien regresi sebesar 0,617 dengan nilai t hitung (CR) 6,417> 1,96 dan P-value sebesar 0.000. Oleh karena itu dapat dijelaskan bahwa inovasi produk dapat mempengaruhi konsumen untuk melakukan pembelian.

\section{Inovasi Produk terhadap Loyalitas Konsumen}

Hipotesis kedua yang dikembangkan dalam penelitian ini adalah bahwa terdapat pengaruh yang positif dan signifikan antara inovasi produk terhadap loyalitas konsumen. Hasil uji hipotesis terbukti bahwa ada pengaruh yang positif dan signifikan antara inovasi produk terhadap loyalitas. Hal ini dapat dilihat dari perolehan nilai koefisien regresi sebesar 0,282 dengan nilai t hitung (CR) 3,368> 1,96 dan P-value sebesar 0.002. Oleh karena itu dapat dijelaskan bahwa inovasi produk dapat mempengaruhi loyalitas pelanggan. 


\section{Pengaruh Keputusan Pembelian terhadap Loyalitas}

Hipotesis kedua yang dikembangkan dalam penelitian ini adalah bahwa terdapat pengaruh yang positif dan signifikan antara keputusan pembelian terhadap loyalitas konsumen. Hasil uji hipotesis terbukti bahwa ada pengaruh yang positif dan signifikan antara keputusan pembelian terhadap loyalitas. Hal ini dapat dilihat dari perolehan nilai koefisien regresi sebesar 0,282 dengan nilai t hitung (CR) 6,326> 1,96 dan P-value sebesar 0.000. Oleh karena itu dapat dijelaskan bahwa inovasi produk dapat mempengaruhi loyalitas pelanggan.

\section{Pengaruh mediasi Keputusan Pembelian terhadap Loyalitas}

Pada hipotesis keempat akan diuji apakah keputusan pembelian dapat memediasi hubungan antara inovasi produk terhadap loyalitas. Pengujian dilakukan dengan Sobel Test. Hasil uji Sobel Test menunjukkan bahwa diperoleh nilai t-hitung sebesar 4.619 dan p-value sebesar 0.000.Hal ini menunjukkan bahwa pengaruh mediasi keputusan pembelianyang membentuk hubungan antarainovasi produk terhadap loyalitas memiliki pengaruh yang positif dan signifikan.

\section{Pembahasan}

Hasil penelitian menunjukkan bahwa loyalitas konsumen pengguna mobil Toyota dipengaruhi oleh inovasi dan keputusan pembelian. Artinya inovasi produk akan membuat pelanggan merasa tertarik untuk melakukan pembelian, dan dari keputusan pembelian tersebut akan terbentuk loyalitas pelanggan atas mobil Toyota Calya di Kota Bogor dan Bekasi.Inovasi produk erat hubungannya dengan daya tarik pelanggan untuk membeli produk. Perusahaan yang mampu melakukan modifikasi produk untuk memberikan nilai tambah baik dari segi model, desain dan fitur produk dapat mempengaruhi keputusan konsumen dalam melakukan pembelian. Keputusan pembelian akan memberikan pengalaman penggunaan produk bagi konsumen. Jika pelanggan memiliki respon yang positif atas pembelian yang dilakukan, hal ini akan membentuk loyalitas terhadap produk tersebut.

Uji hipotesis pertama telah dilakukan dan ditemukan adanya pengaruh yang positif dan signifikan antara inovasi produk terhadap keputusan pembelian mobil merek Toyota Calya di Kota Bogor dan Bekasi. Temuan adanya pengaruh antara inovasi produk terhadap keputusan pembelian diperkuat dengan temuan yang dilakukan oleh (Tandia \& Iriani, 2018) bahwa inovasi produk secara signifikan mempengaruhi keputusan pembelian. Hasil penelitian yang dilakukan oleh Al rasyid \& Tri Indah (2018) menunjukkan bahwa inovasi produk merupakan salah satu faktor yang mempengaruhi konsumen dalam pengambilakn keputusan pembelian. Dengan kata lain bahwa sebelum membeli sebuah produk, konsumen akan memperhatikan inovasi dari produk tersebut. Hal ini akan menjadi daya tarik konsumen untuk melakukan pembelian.

Hasil pengujian hipotesis kedua juga menunjukkan bahwa pengaruh antara inovasi produk terhadap loyalitas konsumen adalah positif dan signifikan. Artinya dengan adanya inovasi produk baik, maka hal tesebut akan membuat konsumen semakin meningkatkan loyaltiasnya terhadap produk merek Toyota Calya di Kabupaten Bogor dan Bekasi. Temuan penelitain ini relevan dengan penelitian penelitain yang dilakukan oleh (Syafrizal et al., 2017) menemukan bahwa ada keterkaitan antara inovasi produk terhadap loyalitas pelanggan. Diperkuat juga dengan penelitian yang dilakukan oleh (Aryoni et al., 2019) menemukan bahwa loyalitas konsumen dipengaruhi oleh inovasi produk. Dengan demikian, dari temuan penelitian ini menunjukkan bahwa inovasi produk merupakan hal yang sangat penting untuk mempertahkan loyalitas konsumen.

Selanjutnya, pengujian hipotesis ketiga juga membuktikan bahwa keputusan pembelian mempengaruhi loyalitas pelanggan. Artinya konsumen yang melakukan pembelian atas mobil merek Toyota Calya di Kota Bogor dan Bekasi akan mempengaruhi kesetiaan sebagai pelanggan. 
Jika pengalamannya dalam melakukan pembelian baik, maka loyalitas pelanggan akan tercipta. Temuan penelitian ini juga didukung dengan penelitian yang dilakukan oleh (Hendriko, 2018) yang menemukan bahwa keputusan pembelian. Temuan yang sama juga ditemukan oleh Rejeki dkk (2015) yang menemukan bahwa keputusan pembelian berpengaruh langsung terhadap loyalitas pelanggan.

\section{Kesimpulandan Saran \\ 5.1.Kesimpulan}

Berdasarkan hasil penelitian dan pembahasan yang telah diuraikan sebelumnya, penulis menyimpulkan bahwa inovasi produk mempengaruhi keputusan pembelian secara positif dan signfikan. Inovasi produk dan keputusan pembelian secara positif dan signifikan mempengaruhi loyalitas pelanggan. Hasil penelitian juga membuktikan bahwa keputusan pembelian secara signifikan memediasi pengaruh inovasi produk terhadap loyalitas pelanggan.

\subsection{Saran}

Loyalitas pelanggan merupakan hal yang sangat penting bagi perusahaan. Pelanggan yang loyal tentu akan mempertahankan kinerja penjualan mobil Toyota Calya di Kota Bogor dan Bekasi, oleh karena itu inovasi harus tetap dilakukan demi untuk mempertahankan loyalitas pengguna mobil Toyota Calya.

\section{References}

Abdjul, R., Soegoto, A. S., \& Soepeno, D. (2018). Analisis Pengaruh Inovasi Produk, Kualitas Pproduk Dan Citra Merek terhadap Keputusan Pembelian Mobil Nissan Grand Livina Pada PT.Wahana Wirawan Manado. Jurnal EMBA: Jurnal Riset Ekonomi, Manajemen, Bisnis Dan Akuntansi, 6(4), 3553-3562. https://doi.org/10.35794/emba.v6i4.21659

Al rasyid, H., \& Tri Indah, A. (2015). Pengaruh Inovasi Produk dan Harga Terhadap Keputusan Pembelian Sepeda Motor Yamaha di Kota Tangerang Selatan. Perspektif, 16(1), 39-49. https://doi.org/2550-1178

Aryoni, Eildine, A., \& Muniroh, L. (2019). Pengaruh inovasi produk terhadap loyalitas konsumen. In Jurnal Manager (Vol. 2). Retrieved from http://ejournal.uikabogor.ac.id/index.php/Manager/index

Bobâlcă, C., Gătej(Bradu), C., \& Ciobanu, O. (2012). Developing a Scale to Measure Customer Loyalty. Procedia Economics and Finance, 3(12), 623-628. https://doi.org/10.1016/s2212-5671(12)00205-5

Byrne, B. M. (2010). Structural Equation Modeling with AMOS. In Structural Equation Modeling with Amos Basic Concepts, Applications, and Programming (2nd ed.). https://doi.org/10.4324/9781410600219

Bulan, T. P. L. (2016). Pengaruh Kualitas Pelayanan dan Harga terhadap Loyalitas Konsumen pada PT. Tiki Jalur Nugraha Ekakurir Agen Kota Langsa. Jurnal Manajemen Dan Keuangan Unsam, 5(2), 592-602.

Ekasari, N., \& Roza, S. (2017). Pengaruh Inovasi Produk Terhadap Keputusan Pembelian Konsumen Bisnis Pada Umkm Keripik Pisang Dharma Jaya. Jurnal Manajemen Terapan Dan Keuangan, 6(03), 147-225.

Hair, J. F. H., Hult, G. T., Ringle, C. M., \& Sarstedt. (2017). A Primer on Partial Least Squares Structural Equation Modelling (PLS-SEM). Los Angeles: Sage Publications.

Hendriko, R. (2018). Pengaruh kualitas produk dan keputusan pembelian terhadap loyalitas pelanggan restoran. Jurnal Riset Sains Manajemen, $2(2), \quad 67-74$. https://doi.org/10.1080/01402390.2011.569130

Https://www.otosia.com/berita/20-mobil-terlaris-kln.html, diakses 17 mei 2019.

Https://otomotif.tempo.co/read/1194011/daihatsu-sigra-masih-menjadi-mobil-terlaris-adm-pada-maret2019

Https://oto.detik.com/mobil/d-5023087/gegara-corona-avanza-bukan-lagi-mobil-paling-laku-di-indonesia, 
Https://www.gridoto.com/read/222165571/rapor-merah-penjualan-lcgc-selama-periode-april-2020-turunhingga-92-persen

Istiyanto, B., Hendratmoko, C., \& Mutmainah, H. (2015). Analisis Pengaruh Harga, Promosi dan Pelayanan Terhadap Keputusan Pembelian Jasa Rental Mobil di Surakarta. Gema, XXVII(49), 15691581 .

Junaedi. (2015). Loyalitas Pelanggan Pemasang Iklan Televisi dalam Acara Tembang Pantura. Yogyakarta : Deepublish.

Kadir, H. A., Syarifuddin, T., Rahman, A., \& Andini, N. (2018). Pengaruh Faktor Gaya Hidup , kelas sosial dan kepribadian Terhadap Keputusan Pembelian Yamaha Matic Mio Sporty di Kota Palu. Sinar Manajemen, 5(2), 112-117.

Keller, K. L. (2013). Strategic Brand Management: Building, Measuring and Managing Brand Equity, 4th Edition. England: Pearson Education Limited.

Khairiyah, D., \& Yunita, M. (2018). Pengaruh Nilai Emosional, Nilai Sosial, Nilai Kualitas Dan Nilai Fungsional Terhadap Keputusan Pembelian Sepeda Motor Merek Tvs Di Kota Bengkulu. EKOMBIS REVIEW: Jurnal Ilmiah Ekonomi Dan Bisnis, 6(2), 132-138.

Rejeki, D. S., H, A. F. D., \& Yulianto, E. (2015). Pengaruh Green Marketing pada Keputusan Pembelian dan Implikasinya terhadap Loyalitas Pelanggan (Studi pada Pelanggan Produk Ramah Lingkungan Kentucky Fried Chicken (KFC) Gerai Royal Plaza, Surabaya). Jurnal Administrasi Bisnis S1 Universitas Brawijaya, 26(1), 86230.

Saputri, R. S. D. (2019). Pengaruh Kualitas Pelayanan dan Harga Terhadap Loyalitas Pelanggan Grab Semarang. CoverAge: Journal of Strategic Communication, 10(1), 46-53.

Schumacker, R. E., \& Lomax, R. G. (2010). A Beginner's Guide to Structural Equation Modeling (3rd ed.). Taylor \& Franciss Group.

Siregar, Z. M. E., \& Lubis, J. (2017). Merit System in The Placement of Civil Servants and its Effect toward Performance of Sub-district Office in Labuhanbatu Region Nort Sumatera. IOP Conference Series: Materials Science and Engineering PAPER, 180. https://doi.org/10.1088/17426596/755/1/011001

Siregar, Z. M. E., Suryana, Ahman, E., \& Senen, S. H. (2019). Does knowledge management enhance innovation: A literature review. International Journal of Scientific and Technology Research, 8(9), 1991-1994. Retrieved from http://www.ijstr.org/final-print/sep2019/Does-Knowledge-ManagementEnhance-Innovation-A-Literature-Review.pdf

Soleha, M., \& S, N. E. P. (2019). Pengaruh Promosi dan Inovasi Produk terhadap Keputusan Pembelian Honda Mobilio. Jurnal Manajemen, 5(2), 34-41.

Sumarsih. (2019). Pengaruh inovasi dan kualitas produk terhadap kepuasan konsumen pada produk Briket (CV. Arang Surabaya Campalagian Polman). Movere Journal, 1(2), 218-231.

Syafrizal, Makmur, \& Seprini. (2017). Analisis Pengaruh Inovasi Produk terhadap Loyalitas Konsumen di Showroom Sepeda Motor Bekas Reski di Pasir Jambu Kecamatan Rambah Kabupaten Rokan Hulu. Jurnal Mahasiswa Prodi Manajemen UPP, 4(1), 110420.

Syamsuri, A. R., \& Siregar, Z. M. E. (2018). Analisis Pelatihan, Disiplin Kerja, Remunerasi, dan Motivasi Berprestasi dengan Kepuasan Kerja Sebagai Variabel Intervening terhadap Kinerja Karyawan. JSHP ( Jurnal Sosial Humaniora Dan Pendidikan), 2(2), 95. https://doi.org/10.32487/jshp.v2i2.470

Tandia, A. T., \& Iriani, S. S. (2018). Pengaruh Inovasi Produk dan Harga terhadap Keputusan Pembelian Suzuki Karimun Wagon R AGS (Studi di Dealer United Motor Centre Jalan Ahmad Yani Surabaya). Jurnal Ilmu Manajemen (JIM), 6(3), 241-247.

Tugiso, I., Haryono, A. T., \& Minarsih, M. M. (2016). Pengaruh relationship marketing, Keamanan, kepercayaan dan kualitas pelayanan terhadap keputusan pembelian online shop dan loyalitas konsumen sebagai variabel intervening studi kasus pada onlineshop "Numira" Semarang. Journal of Management, 2(2), 1-18. $\quad$ Retrieved from https://jurnal.unpand.ac.id/index.php/MS/article/view/558/543

Tumembouw, F. D., Mandey, S. L., \& Loindong, S. (2019). Analisis kualitas produk dan harga terhadap keputusan pembelian mobil toyota agya di manado (Studi Kasus: PT Hasjrat Abadi ). Jurnal EMBA: Jurnal Riset Ekonomi, Manajemen, Bisnis Dan Akuntansi, 7(1), 481-490. 